\title{
Települési környezeti minöség, fenntarthatóság és városmarketing - különös tekintettel a zajterhelésre és az önkormányzatok szerepére
}

\section{Urban environmental quality, sustainability and place marketing with special focus on noise nuisance and the role of municipalities}

\author{
BAROS ZOLTÁN
}

KULCSSZAVAK: települési környezeti minőség, zajterhelés, városmarketing, szlogenek, kérdőíves felmérés

ABSZTRAKT: A zajterhelés napjainkra az egyik legtipikusabb, egyre több embert és egyre nagyobb mértékben érintő városi környezeti problémává vált, amelynek megoldásában kiemelt szerep jut a települési önkormányzatoknak. A tanulmány célja, hogy bemutassa az önkormányzatok ezzel kapcsolatos tevékenységéhez kapcsolódó lakossági véleményeket, valamint, hogy áttekintse a települési környezet megítélésében végbement változásokat és a települési környezeti minőség, azon belül az akusztikai környezet mint adottság felhasználási lehetőségeit a városmarketing-tevékenység során. Ehhez a szerző egyrészł hazai települések szlogenjeit (a környezet, az élhetőség azokban történő megjelenését) vizsgálja, illetve egy esettanulmányban mutatja be annak lehetséges felhasználását. Másrészł egy Debrecenben elvégzett, a zajterhelés lakossági megitélésének feltérképezését célzó kérdőives felmérés eredményeire támaszkodva a zajvédelemmel, azon belül az önkormányza† szerepvállalásával kapcsolatos véleményeket ismerteti.

A vizsgálatok eredményei azt mutatják, hogy a hazai települések szlogenjeiben a környezeti minőség, hasonlóan más egyedi értékekhez (helyi termékek, hagyományok, élhetőség), háttérbe szorul, sok esetben kiaknázatlan marad, az alkalmazott szlogenek pedig az esetek többségében nem járulnak hozzá a település adottságainak erősitéséhez. A kérdőives felmérés eredményei a város területét érintő zajvédelem helyzetének megitéléséről igen kedvezőtlen képet festenek: a megkérdezettek közel kétharmada szerint a településen nem fektetnek elég hangsúlyt a zajjal kapcsolatos (elsősorban a közúti közlekedésből eredő) problémák kezelésére, pedig azł az eredmények alapján a lakosság egyértelmúen az önkormányzat feladatának tekinti. A válaszadók ugyanakkor minimális szerepet tulajdonítanak a civil szervezeteknek - jóllehet a hatékonyabb megoldást jól szolgálná a velük történő együttmúködés.

KEYWORDS: urban environmental quality, noise nuisance, place marketing, slogans, questionnaire survey

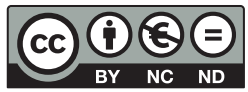


ABSTRACT: Noise nuisance or noise pollution has become one of the most typical urban environmental problems increasingly annoying a growing number of citizens. In order to combat it, municipalities have an outstanding role to play. This study intends both to present public opinions related to the municipalities' role and to provide a review of changes taking place in the appraisal of urban environments and of the potential utilisation of urban environmental quality including the acoustic environment as an asset in city marketing. In order to meet these objectives, slogans advertising Hungarian towns were analysed, especially for any reference to environmental quality and liveability. The potential use of such slogans is described in a case study. In addition, some results of a questionnaire survey carried out in the town of Debrecen are presented. It dealt with noise-nuisance-related public opinions, focusing on noise prevention issues and on the role of the local municipality.

The results suggest that in nearly $25 \%$ of the cases the slogans emphasize the fact that a town is the centre or the 'capital' of a given region. Their importance is intended to be thus accentuated, putting such towns higher in the 'hierarchy' and distinguishing them from others. Environmental quality along with other distinctive assets (e.g. local products, traditions and liveability) are generally ignored, and the slogans actually chosen do not support city marketing in most cases. This is also true for Debrecen whose slogan can be considered to be utterly banal, not reflecting the town's features and values, namely its rich cultural life, traditions and its schooltown character, what it has to offer for tourists or investors, nor marketing its uniqueness. Therefore the city cannot be regarded as being well marketed, as its marketing is not covering local features, products and services.

The results of the questionnaire survey show a rather disadvantageous picture with regard to noise prevention in the town. This, according to the noise complaint index (established to measure spatial differences in noise-nuisance-related public opinion), especially applies to the Central-Northern district (primarily the Town Centre) and the Eastern districts. The former can be explained by the major streets leading through the district, whereas the second is an important feedback considering the district's essentially garden-suburb character (associated by many with a more silent residential environment). According to nearly two thirds of the respondents, no adequate emphasis is put on handling (primarily road-traffic induced) noise-related problems. According to public opinions, this is clearly considered to be a task of the municipality. Although cooperation with relevant civil organisations would facilitate implementing more effective solutions, only a minor role is attributed to them.

\section{Bevezetés - A települési környezet felértékelödése}

Egy-egy településen belül számos olyan tényező létezik, amely jelentős megítélésbeli különbségeket eredményez az ott lakó népesség szempontjából (Gyenizse 2009). Ezek között szerepelnek a település környezeti elemei is (klimatikus viszonyok, zaj stb.), amelyek nyomán a település egyes részei vonzóvá válhatnak, míg mások hátrányos színben jelennek meg (Berki, Csapó 2006, Dövényi, Kovács 2006, Elekes 2008). Ennek következtében a jobb életminőséget kínáló városrészek nemcsak mint lakóhely, hanem mint munkahely is felértékelődnek (Izsák, Probáld 2008), az életminőség területi különbségei pedig erőteljesen kifejezésre jutnak az ingatlanok értékében (Izsák, Probáld, Uzzoli 2008). Ezek a városrészekre jellemző folyamatok ugyanakkor kihatnak a település egészének 
megítélésére, versenyképességére, sikerességére is, azaz befolyásolják az önkormányzati rendszer bevezetésével megindult, új alapokra helyezett városfejlődést (Koncz 2008, Bujdosó 1999).

Az általánosan kedvezőtlenné váló települési környezetben a hosszú távú versenyképesség megkerülhetetlen feltétele a fenntarthatóság, illetve annak egyik elemeként a gazdaság és társadalom számára nélkülözhetetlen szolgáltatásokat nyújtó természeti tőke (ezt esetünkben talán célszerübb környezeti tőkeként említeni), amely egy speciális jellemzőkkel rendelkező tőketípus; bizonyos elemei jelen tudásunk alapján mindenféle emberi szükségletkielégítési cselekvés alapját képezik, és semmi mással nem helyettesíthetők (Málovics, Ván 2008).

A környezeti tőke helye, annak megítélése némiképp ellentmondásosnak tekinthető. Míg Kiss (2006) szerint a városi gazdaság fejlődését ma sok tekintetben jobban szolgálja az élhető környezet, mint a gazdaságot kiszolgáló „kemény” (műszaki) infrastruktúra megléte, addig a versenyképesség széles körben elfogadott piramismodelljében (Lengyel 2000 és Gardiner et al. 2004) a természeti tőke nem szerepel kiemelt helyen: a „környezet minősége” a sikerességi faktorok, a versenyképesség hosszú távú forrásai között jelenik meg. A lakhatóság, azon belül az egészséges környezet pedig a fenntartható városfejlödés Világbank (WB 2000) által meghatározott négy dimenziójának egyikét képviseli.

\section{A települések környezeti minöségének jelentösége marketingtevékenységükben}

A városok fenntarthatóbbá, élhetőbbé tételében fontos szerepet játszanak a helyi döntéshozók (Csete 2007). Különösen igaz ez például olyan - egyre több embert és egyre növekvő mértékben érintő - környezeti problémák esetében, mint a környezeti zaj, amely kezelése szempontjából is sajátosnak tekinthető: helyi jellegű problémáról van szó, amelynek forrása nem helyi eredetű. Megoldása, az ellene folytatott hatásos védekezés ugyanakkor feltételezi a komoly helyi és nemzetközi szintű problémakezelést (Bite, Póta 2001). Emellett mind az EU-s, mind a hazai szabályozás megköveteli a szubszidiaritás és a közös felelősség elvének az eddiginél nagyobb mértékü érvényesítését (MTA MTO AKB 2003).

Az emberek a világ minden részén jobb minőségű és biztonságosabb lakóhelyet keresnek. Meier (2003) szerint a jó minőség részben olyan természeti és épített környezetet jelöl, amely egészséges. Az egészségérzet nagymértékben befolyásolja az egyén szubjektív jólétét. A lakó védelme a környezetből érkező zajhatások ellen, (másképp fogalmazva) a nyugalmas, csendes lakóhelyi környezet utáni vágy, a jobb akusztikai komfort a városi lakóhely-változtatások tekintélyes részét motiválja. A Köln belvárosából a városkörnyékre történő költözések 15\%-ánál volt ez meghatározó tényező (Penn-Bressel 1988) már az 1980-as évek végén is. De igaz ennek az ellenkezője is. Számos tanulmány jelzi, 
hogy a természetes elemeket (amelyek közé a csend besorolható) is tartalmazó épített környezet valószínủbben lesz kedvelt, mint a természetes elemet nem tartalmazó (Herzog 1989).

Az életminőség javításához olyan életfeltételeket kell teremteni, hogy azok a lehető legtöbb ember számára lehetővé tegyék szükségleteik kielégítését (Maderthaner 1995). A fenntartható fejlődés célja a szociális jólét előmozdítása a környezet eltartóképességének keretei között. A helyi szintü megoldások ezek megvalósítását jelentik.

A zaj elleni harc kétirányú: műszaki és egészségügyi, melyekhez a zajcsökkentés aktív (elsődleges) és passzív (másodlagos) módjai állnak rendelkezésre. Hatékony zajvédelem csak a különböző típusú intézkedések együttes végrehajtásával valósítható meg. Popp (2004) vizsgálatai alapján ezek hatásai egy átlagos adottságú, $\mathrm{kb}$. 30000 fós (hipotetikus) városra vetítve a lakosság mintegy 50\%-át érinthetik, átlagosan $5 \mathrm{dBA}$, maximálisan $14 \mathrm{dBA}$ zajcsökkenést, számszerüsítve évenként 2 millió euró megtakarítást eredményezve.

A zajvédelem és a települési önkormányzatok kapcsolata meglehetősen sokrétü. A zajprobléma összetett feladat elé állítja az önkormányzatokat, ennek megoldása (ahogy az a fentiekből kitűnik) számukra jól felfogott gazdasági-társadalmi és várospolitikai érdek. E relációról a nemzetközi szakirodalom (pl. Axelsson 1996, Díaz, Pedrero 2006, Kang 2005, Nardo 2004, Skinner, Grimwood 2005, Yilmaz, Özer 2005) széles körü áttekintést ad. Ezek középpontjában általában az alábbi témák szerepelnek:

- a zajprobléma jellege, nagysága, eredete;

- a zajterhelés hatásai;

- települési zajvédelem, megoldási-megelőzési lehetőségek, intézkedési tervek;

- stratégiai zajtérképek és

- problémamegoldás a fenntartható településfejlesztés tükrében.

Tekintettel a probléma és a megoldási lehetőségek sokszínűségére, valamint a helyi szint jelentőségében, a szabályozásban, ezáltal a szükséges beavatkozások sajátossága tekintetében jelentkező különbségekre, e tanulmánynak nem célja ezek áttekintése. Mindössze annyit kíván megfogalmazni, hogy az általánosan elfogadott zajvédelmi eszközök önálló vagy kombinált, esetleg az adott településre adaptált végrehajtásával mutatnak be olyan eredményeket, amelyek más települések számára követendő (vagy legalábbis követhető) példával szolgálnak akusztikai környezetük mint környezeti tőkéjük egyik eleme jobbá tétele érdekében.

Az önkormányzatok feladatai röviden az alábbiakban foglalhatók össze:

- települési zajvédelmi intézkedések megvalósítása;

- a csendesebb környezet felhasználása a település marketingtevékenységében;

- az eredmények kommunikálása.

Jelen tanulmány tehát a továbbiakban az utóbbi két pont jelentőségét kívánja részletesebben tárgyalni. Az, hogy egy-egy város milyen módon és mértékben tudja értékesíteni környezeti tőkéjét, részben a helyi önkormányzat 
marketingtevékenységének, kommunikációjának függvénye. Ashworth és Voogd (1994) ennek sikerességét olyan feltételek meglétében látja, mint a környezeti minőség (így valós termék reklámozása történik meg); tágabb értelemben pedig abban, hogy a város mint lakó- és munkahely, valamint a rekreáció és a befektetések számára milyen értéket képvisel - ami végső soron a környezettudatos településfejlesztés részének tekinthető. Mintegy visszahatásként Kovács (2006) a környezeti tudatosság függvényének tekinti a települési környezet megújulását és fenntarthatóságát. Ezen megközelítés mintegy csúcsaként az ökocentrikus várostervezés (Lichtenberger 1993) áll.

A marketing alapjában két irányt körvonalaz: az egyik a kidolgozott „termék" üzleti elfogadtatásáról szól, a másik olyan környezetet, helyzetérzést teremt, amely kitermeli a termék iránti igényt (Nagy 2005). A város az előbbi kategóriába sorolható, azaz olyan „terméknek” kell tekinteni, amelyet a piacon értékesíteni akarnak (Kozma 2002). Ezt a terméket a vevőhöz az önkormányzat fejlesztési tevékenységeivel, illetve kommunikációs képességeivel képes eljuttatni (Rechnitzer 2007).

A környezeti minőség mint termékelem (a városok egyik lehetséges vonzereje és kínálati eleme) a településmarketing célcsoportjainál az érzékszervekkel mérhető előnyök között (nyugalom, csend, tisztaság stb.) jelenik meg (Ashworth és Voogd 1997). A turisták, valamint a cégek és háztartások preferenciái között nemcsak a tiszta, olcsó, zöld városperemi területek töltenek be egyre fontosabb szerepet (Bogunovich 2009), de ugyanígy felértékelődött körükben a kedvező akusztikai környezet is. A vevőértékek ezen változásainak felismerése és felhasználása a város javára (Fojtik 1999) a várospolitika feladatának tekinthető - amelynek területei érintik a termékfejlesztést (a kedvező területi adottságok felismerését és jobb kihasználását, a megfelelő termékstratégia kiválasztását), valamint a helyes piaci pozicionálást és az előnyös akusztikai környezet reklámozását is (1. ábra).

Emellett meg kell jegyezni azt is, hogy a települések között kiélezetté vált versenyhelyzetben a keresletorientáció növekedése a lakosság esetében abban is megnyilvánul, hogy sokan képesek és hajlandóak a magasabb színvonalú „áruért” magasabb összeget fizetni. A különböző társadalmi-gazdasági csoportok igényeinek felismerése végső soron hozzájárul a döntéshozatali folyamat helyes megvalósításához (Drakakis-Smith 1980), egyben a sikeres település kialakítása és fenntartása érdekében kialakított fejlesztési terv megfogalmazásában (Rechnitzer 2007) is alapvető szerepet játszik.

Ennek oly módon kell történnie, hogy a településtervek egyrészt a tényleges települési reálfolyamatok kezelésén alapuljanak, másrészt az újító ötletek számára is megfelelő teret adjanak (Nagy 2005). Ez az innovatív magatartás különösen indokolható a hazai települések esetében, amelyek marketingaktivitása sok esetben még mindig messze elmarad a nyugat-európai szinttől (Herendy, Murányi 2009).

A helyi döntéshozók ezen megközelítése nemcsak a település fenntarthatóságának, élhetőségének, zöld arculatának hirdetésében fontos, de hozzájárul ver- 
1. ábra: Az akusztikai környezet felhasználása a településmarketing folyamatának elemeiben

The use of acoustic environment in the elements of the place marketing process

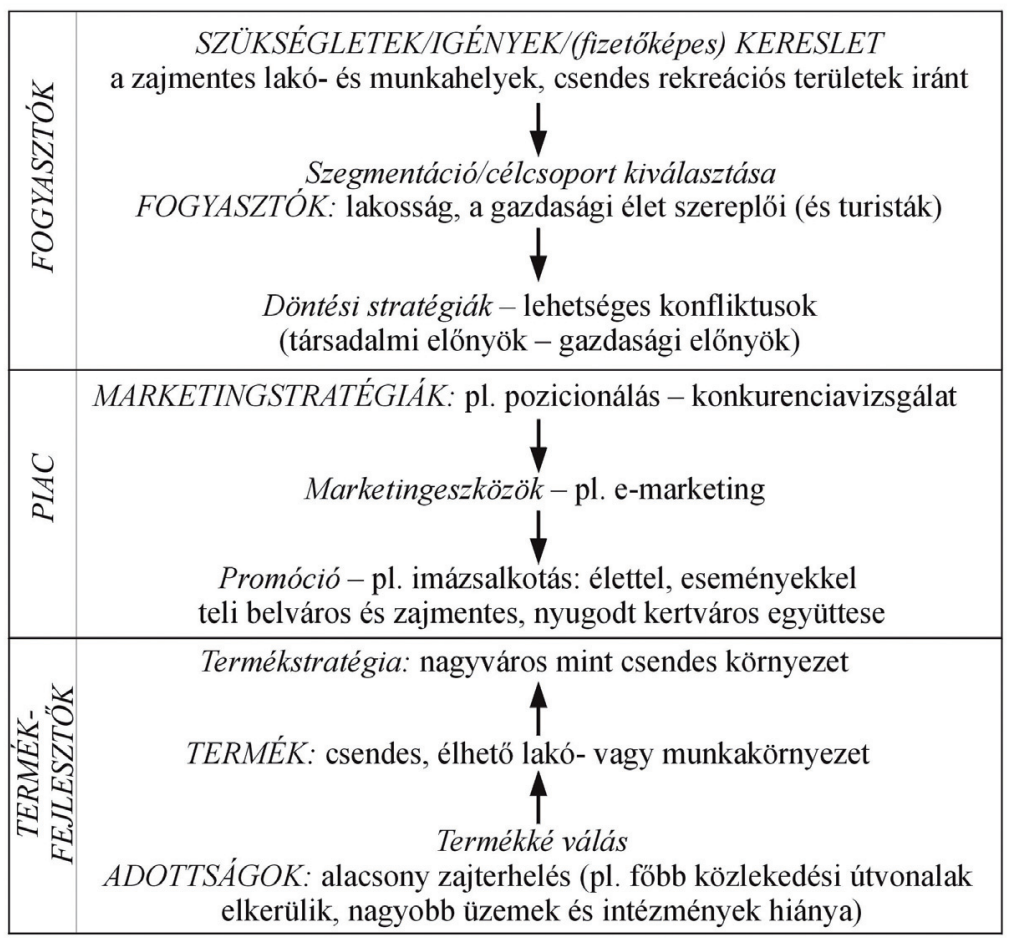

Forrás: Ashworth, Voogd 1997 alapján, módosítva.

senyképességének növeléséhez, mintegy magasabb termékszínvonalat kínálva, és ezzel biztosítva a településen élők viszonylagos jólétét. Indirekt módon pedig innovatív módszerek elterjesztésével segíti elő a településen belül egy környezettudatos fogyasztói réteg kialakulását (Csete 2007).

Az önkormányzat elvégzett zajvédelmi intézkedéseinek, illetve az akusztikai környezet jobb minőségét is felhasználó marketingtevékenységének igazi eredményei akkor fognak megmutatkozni, ha azokhoz hatékony kommunikáció párosul. A kommunikáció jelentőségét alátámasztja az a megállapítás is, amely szerint a marketingorientált településfejlesztés elméletével összhangban a jólétet a versenyelőnyök feltárása, kialakítása, megvalósítása és kommunikálása biztosítja (Rechnitzer 2007), amelynek része kell legyen a negatív környezeti hatásoktól való távolmaradásra törekvés (Garamhegyi 2000) is.

A zöld arculat, a környezeti minőség kommunikációja nem újkeletű tevékenység, arra a kontinens több tájáról, sőt az Egyesült Államokból is találunk példákat. A lakosság mint célcsoport felé irányuló kommunikáció esetében kulcsszóvá az egészséges otthon vált, míg célterületként a szuburbia került elő- 
térbe. Nagy-Britanniában évszázadokon át az elővárosi-kertvárosi lét előnyei a társadalom előkelő rétegeinek kiváltságai közé számítottak (Ward 1998), ezen a helyzeten a nagyvárosok gyors urbanizációja, modern nagyvárossá válása változtatott gyökeresen. A külvárosi életformát különböző tartalommal töltötték meg az idők folyamán, ilyen volt a saját otthon, a nyugodt családi élettel, a természeti környezettel vagy a tágabb lakóközösséggel való szorosabb, harmonikus kapcsolat idealizált, romantikus képe, amely valós alternatívát kínált a belvárossal szemben. Jelentette a városi léttől való menekülést is - nemcsak a tiszta levegő vagy a zöld felé, hanem a nemkívánatos társadalmi jelenségek kizárása felé is (Ward 1998). Emellett ugyanígy vált az egészségesebb életforma jelképévé is, amely a XIX. századtól - a növekvő légszennyezés következtében a várostervezésben jelent meg üzenetként (Cadbury 1915).

Gold és Ward (1994) alapján egy, a települési környezet értékeit hirdető marketingtevékenység során az alábbi szempontokat szükséges érvényesíteni:

- attraktív imázs megalkotása;

- pozitív érzés kialakítása a helyről;

- piacorientáltság, versenyhelyzet más településekkel;

- erős konceptuális alap alkalmazása.

Ennek megvalósítása több szempontból is akadályokba ütközhet: ezek közül Barke és Harrop (1994) az egységes imázs kialakítását említi. A város heterogén termékek összességeként fogható fel, így az egyes elemek értékesítése konfliktusokat teremthet, amire jó példa a városi környezet mint termékelem, illetve azon belül a jelen tanulmány középpontjában álló zajterhelés is. A gépkocsiállomány növekedése egyszerre jelenti a társadalmi jólét bizonyos szintjének elérését, valamint növekvő mértékű környezetterhelést. Másrészt, ugyan Kotler et al. (1993) felhívja a figyelmet az üzenet megkülönböztető jellegének fontosságára, a települések számos egyedi adottsága helyett inkább a kompetitív tulajdonságok marketingje dominál, ezek ugyanis könnyebben elérhetők (Ashworth és Voogd 1994). E „biztonsági” stratégia alkalmazását erősíti a szerzők azon megállapítása is, amely szerint nemcsak az információ potenciális fogyasztókhoz történő eljuttatása fontos, hanem az a törekvés is, hogy azt elfogadják.

Az akusztikai környezet mint termék marketingje során sor kerülhet pozitív tulajdonságainak és versenyképes jellegének reklámozására, valamint az önkormányzatok zajvédelmi politikájának kommunikációjára, amelyet Nardo (2004) alapján az alábbi fontosabb szegmensekre tagolhatunk:

- a zajcsökkentési törekvések és alkalmazások erősítése,

- az emissziós értékek csökkentése és azok érvényre juttatása,

- a zajcsökkentési intézkedések és a közlekedés tervezésének összehangolása,

- a zajcsökkentési intézkedések összehangolása a várostervezési elképzelésekkel.

A települések önmeghatározásának megnyilvánulásai a szlogenek (jelmondatok), amelyek feladata a település sajátos jelleggel történő felruházása, kiemelése a vetélytársak sorából (Kozma 2002, Piskóti et al. 2002), és amelyek a 
települések vizuális arculatának részét képezik. Ezek elméletben társadalmi konszenzust tükröznek, sok esetben éppen lakossági vélemények alapján határozzák meg őket. A szlogenekben történő felhasználáskor az utolsó három szempont - túlságosan specifikus jellege miatt - kevésbé érvényesülhet (a fogyasztók számára nehezen érthető, ebből következően nehezen befogadható). Így a további vizsgálatok az első szempontra korlátozódnak: milyen módon és mértékben jelenik meg a csendes környezet a települések jelmondataiban.

\section{Alkalmazott módszerek és adatbázisok}

Két vizsgálat néhány eredményét kívánjuk bemutatni. Az első esetében hazai városok szlogenjeinek vizsgálatára került sor azzal a céllal, hogy a települési környezet és minőség azokban történő felhasználásáról kapjak közelebbi képet. Esetünkben hazánk városi ranggal bíró (a vizsgálat időpontjában összesen 328) településének szlogenjeit tekintettük át, amihez Kozma (2005) publikációjához használt adatbázisát frissítettük. Az adatbázis alapját az Utazás kiállításokon használt kiadványok, valamint a települések internetes honlapjai adták, ezek alapján összesen 119 szlogent sikerült kigyüjteni. (Több település esetében egynél több jelmondat is szerepel az adatbázisban.) Tartalmuk alapján ezek 10 kategóriába kerültek besorolásra (3. ábra). Egyes esetekben a jelmondatok 2 kategóriához is hozzárendelhetők voltak, így egy összesen 126 tételből álló adatbázis állt rendelkezésre. A jelmondatok kategóriákba sorolását követően az azok esetében a környezetvédelem, illetve specifikusan a csendes környezet megjelenésének, konkrét mondanivalójának elemzését végeztük el.

A másik vizsgálat célja a zajterhelés mint környezeti probléma csökkentésében érdekelt egyik potenciális szereplő - a települési önkormányzat - szerepvállalásának lehetőségeivel és megítélésével kapcsolatos lakossági vélemények megismerése volt. Ehhez a Debrecenben elvégzett, a lakosság zajterheléssel kapcsolatos attitüdjének feltárását célzó kérdőíves felmérés (Baros, Gajdátsy 2008) eredményeit használtuk fel. A zajterhelés ilyen típusú vizsgálata nem példa nélküli: a városi zajterheléshez kapcsolódó kutatásokban az utóbbi évek során megfigyelhető egyik tendencia az, hogy a müszeres mérések mellett egyre nagyobb hangsúlyt kapnak a lakossági vélemények felmérésére irányuló tudományos munkák (Kang 2005). (Az ilyen típusú munkák, amelyek integrálják a pszichológia, a zajminőség-kutatás és a társadalomtudományok módszereit, illetve kreatív módon teremtenek kapcsolatot a földrajz térbeli és társadalmikulturális dimenziói között (Kwan 2004), az úgynevezett „hibrid geográfia” tárgykörébe tartoznak.)

Az elvégzett kvótás felmérés 909 főt érintett, a lakosságszámra vonatkozó kvótákat a 2001. évi népszámlálási adatokból arányosítva, életkor és nem szerint határoztuk meg. A mintavételnél arra törekedtünk, hogy a megkérdezettek 
megfelelő arányban reprezentálják a város területének különböző típusú beépítésü területeit és városrészeit.

A kérdőíves felmérés helyszínéül a város összesen 134 utcáját választottuk ki, amelyeket a közúti forgalom alapján három kategóriába (forgalmas, közepes és kis forgalmú) soroltuk, a vizsgálati területet pedig négy városrészre tagoltuk (2. ábra), az alábbiak szerint:

- Északi és Központi városrész: döntően a Belváros hagyományos beépítésű területeit, valamint a lakótelepi beépítést, kisebb részben a Nagyerdőt délről övező villanegyedet fogalja magában;

- Nyugati városrész: döntően kertvárosias lakóterület, valamint lakótelepek, a város nyugati szélén ipari üzemi területekkel;

- Déli városrész: jórészt szintén kertvárosi beépítésű terület, kisebb lakóteleppel és ipari üzemi területekkel, valamint itt található a város repülőtere is;

- Keleti városrész: uralkodóan kertvárosi beépítésű terület, kisebb ipari területtel.

Fentiek alapján, a lehető legteljesebb területi lefedettség biztosítására törekedtünk, valamint arra, hogy a válaszok reprezentatív képet adjanak a város lakosságának zajexpozíciójáról.

2. ábra: A városrészek határai, valamint a kiválasztott utcák területi megoszlása forgalmi szintek szerint

The designated districts and the spatial distribution of the selected streets by the level of traffic

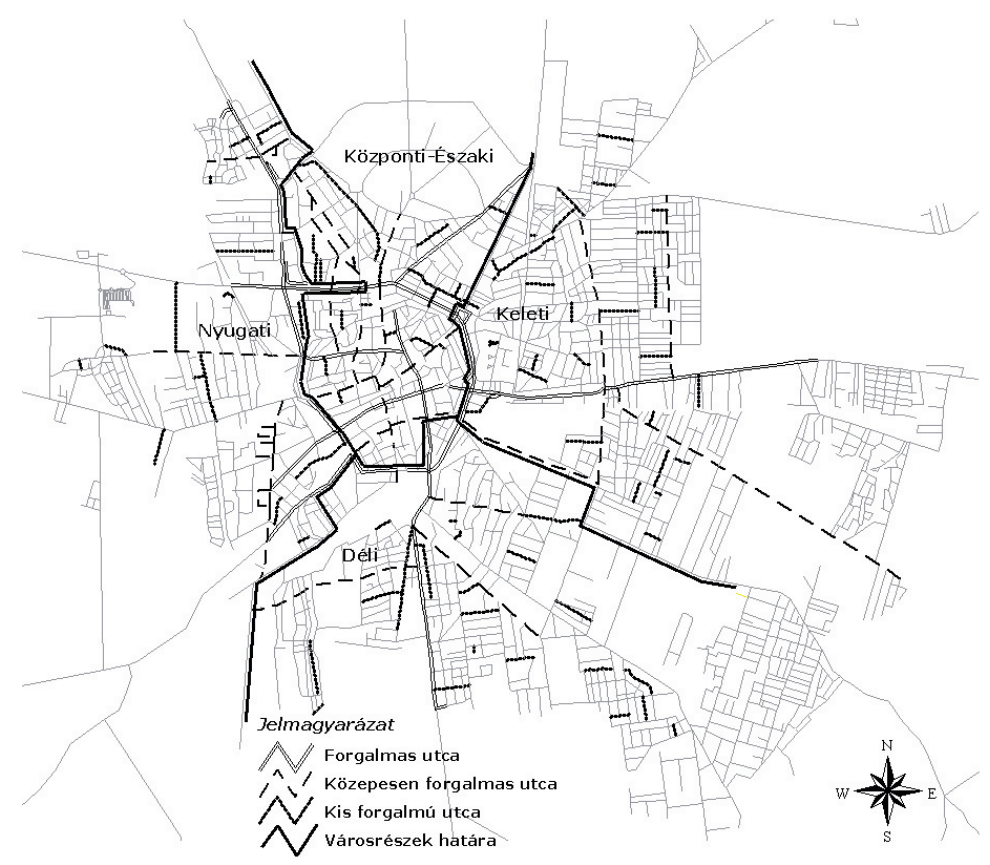

Forrás: saját szerkesztés. 
A lakossági vélemények feltérképezése arra irányult, hogy a megkérdezetteket (lakó- és munkahelyükön, valamint az utcán) érő zajhatások milyen mértékü és jellegü zavaró hatást váltanak ki, mit tartanak a legfontosabb és leginkább zavaró forrásoknak. Kérdéseket tettünk fel a jelentkező zajhatás időpontját és időtartamát, valamint egészségre és életvitelre gyakorolt hatásait illetően, és arról, hogy a válaszadók melyeket tekintik a város legnagyobb zajterhelésnek kitett pontjainak. Az utolsó kérdéscsoport a lehetséges és már megtett zajvédelmi intézkedések megítélésére vonatkozott.

A lakosságot érő zajterheléshez kapcsolódó vélemények területi sajátosságainak vizsgálatához egy, a zajterheléssel kapcsolatos lakossági vélemények mérésére alkalmas mutatószám (zajpanaszindex) került meghatározásra, amely az adott utca zajminőségének egyszerủ mutatójaként értelmezhető, és az alábbiak szerint számítható ki:

$$
\mathrm{z}_{\mathrm{p}}=\left\{\frac{z}{[1 /(k+t)] / n}\right\} / 100
$$

ahol $\mathrm{z}_{\mathrm{p}}$ a zajpanaszindex értéke, $\mathrm{z}$ a zavarás mértéke, $\mathrm{k}$ az életkor, $\mathrm{t}$ a lakóhelyen eltöltött idő, $\mathrm{n}$ az adott utcán kitöltött kérdőívek száma.

A mutató kapott értékei a felmérésbe bevont utcákra történő kiszámítás után a rendelkezésre álló alaptérképen kerültek ábrázolásra, így egy „zajpanasz-térkép" készült el.

\section{Eredmények}

\section{Hazai városok szlogenjeinek vizsgálata}

A vizsgált jelmondatok egyes kategóriák szerinti eloszlását a 3. ábra mutatja, amely alapján 1 kategória jelentősebb aránya rajzolódik ki: 31 esetben (tehát közel 25\%-os arányban) a szlogenek az adott település központiságát hangsúlyozzák, hivatkozva arra, hogy városuk egy-egy tájegység fövárosa, központja, valamint, hogy (ezekkel összefüggésben) összekötő funkciót tölt be. Ezzel mintegy saját fontosságukat igyekeznek hangsúlyozni, kiemelve, a hierarchia magasabb fokára helyezve városukat, ilyen módon megkülönböztetve magukat a térség többi településétől. Ez sok esetben indokolható, azonban olyan kisebb települések esetében, amelyek például egy rész-nagytáj központjai, kissé ellentmondásos tűnik. Jó példa erre Kunszentmiklós (lakosságszáma 2010-ben közel 9000 fö), amely „a Felső-Kiskunság fővárosa”. Tükrözhetik ezek a jelmondatok azt a fajta versenykényszert, aminek következtében ezek a települések külső hatásra hozzák létre saját szlogenjüket. Kérdéses azonban, hogy a jelmondat hi- 
3. ábra: A hazai városok szlogenjeinek száma tematika szerint Thematics of the slogens of the Hungarian towns

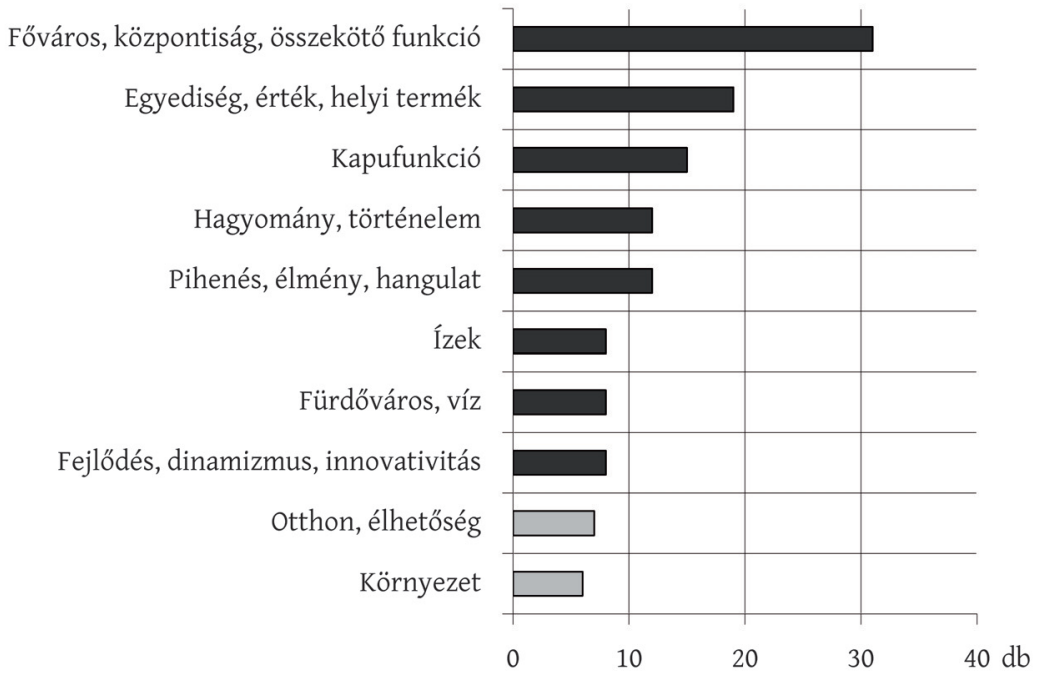

Forrás: saját szerkesztés.

ánya vagy annak nem megfelelősége jelent nagyobb versenyhátrányt a konkurens településekkel szemben.

A második nagy csoportot a 10-20 esetben előforduló szlogenek képviselik. Ezekhez részben a kedvező földrajzi fekvés másik típusa, a kapufunkció megjelenése társítható, amellyel 15 város esetében találkozunk, és a központisággal hasonló jellegzetességeket mutat. Szintén ebbe a csoportba tartoznak az egyediség, egyedi érték, helyi termékek (19 db), valamint a hagyomány és történelem (12 db) kategóriák, amelyek egy-egy település saját értékeit talán leginkább tükrözik. A két kategória szerepét jól mutatja, hogy ezek összesen szintén (a központisággal megegyező mértékben) 31 esetben fordulnak elő. Végül idesorolhatóak az egyegy hangulatot, pihenést vagy élményt hirdető jelmondatok is, amelyek alacsony száma talán ezeknek az idegenforgalomhoz való kapcsolódása miatt lehet némiképp meglepő, különösen annak fényében, hogy a turizmus a hazai települések döntő többségében a fejlesztési prioritások között szerepel.

A fennmaradó 5 kategória mindegyike 10-nél kevesebb esetben fordul elő: a vizek jelenléte vagy a fürdővárosjelleg kiemelése, a gasztronómia (azon belül is elsősorban a bor), valamint a fejlődés, innovativitás, dinamizmus kategóriák 8-8 esetben kerültek felhasználásra. Előbbi kettő olyan jellegzetességekre utal, amelyekre hazánk méltán büszke, és amelyek szintén a turizmus alapját képezik. Utóbbi pedig elsősorban a befektetők, valamint a lakosság számára lehet vonzó tényező; ezt a lehetőséget kisvárosok, kisközépvárosok, illetve nehézipari 
múlttal vagy jelennel rendelkező városok (Csorvás, Bóly, Százhalombatta stb.) használják fel.

A vizsgálat szempontjából fontos két tényező - a település környezeti minősége, valamint élhetősége és az otthon megjelenése - a két utolsó helyet foglalja el (6, illetve 7 esetben fordul elö), azaz a hazai önkormányzatok által legkevésbé favorizált, hirdetendő adottságok, illetve előnyök közé tartozik. A város élhetősége olyan esetekben szerepel, mint például Siófok („Az élet mint minőség”), Szombathely („Az otthonosság városa”) vagy Nyíregyháza („A város, ahol otthon érzi magát"). A nehézipari múltjával küszködő Ajka esetében a korábbi és a jelenlegi szlogen az élhetőséget és a dinamizmust tükrözi („Az élhető város”; „Egy város tele élettel, változással, tele mondanivalóval"), míg Mosonmagyaróvár és Szigetszentmiklós kapcsán a közösséghez tartozás hangsúlyozása („A mi városunk”, illetve „Otthonunk, Szigetszentmiklós”) jelent többlettartalmat. A települési környezet egy kivétellel (Érd) kisebb, 20000 fönél alacsonyabb lakosságszámú városoknál jelenik meg, ezek egy részénél (Budakeszi - „Város a természet ölén” vagy Lengyeltóti - „A csalogányok völgye) a természetközeliséget hirdetve, míg más városoknál azok virágos, zöld jellege kerül középpontba: Csongrád - „A vizek és parkok városa” vagy Érd - „A virágzó kertváros”. Ez utóbbi ismét kettős értelemmel bír, hiszen utal egyúttal a település fejlődésére is.

Egyetlen olyan városunk van, amelynek szlogenjeiben a csend megjelenik: Zsámbék („Csendes vidék a nagyváros tövében”). Ez, a nagyvároshoz közeli csendes környezet hirdetése akár követendő példának is tekinthető. Az adatbázisban nem szereplő Kőkapu szintén így hirdeti magát: „... ahol a csend kezdődik.” Edelény kapcsán pedig több forrás (pl. Cserehát turistája ajánló - members.upclive.hu 2010) is megjegyzi, hogy csakúgy, mint a térség többi településére, tökéletesen illik rá a Cserehát szlogenje - „Ahol a csend még hallható”. A város ugyanakkor ettől eltérő tartalmú jelmondatot alkalmaz.

A nemzetközi gyakorlat ettől lényegesen eltérő képet mutat, a számos példa közül talán egyet érdemes kiemelni: a Møn-sziget (Dánia) szlogenjét. A sziget, annak ellenére, hogy az ország egyik legnépszerübb desztinációja, megőrizte háborítatlan természeti környezetét. Fehér szikláival, homokos tengerpartjával és Stege városkájával ideális lehetőségeket kínál a csendes, vidéki környezetben pihenni vágyóknak. A „The Sound of Silence” (A csend hangja) jelmondat nemcsak a hely adottságait figyelembe véve találó, hanem szellemesnek, sőt sokak számára jól ismertnek számít, nagyban elősegítve annak elfogadását, hanem hatékonyan erősíti a felkínált turisztikai vonzerőket is.

A következőkben egy hazai nagyváros szlogenjének részletesebb elemzését kívánjuk bemutatni. 


\section{Esettanulmány: Debrecen város szlogenjének értékelése, az akusztikai környezet felhasználásának lehetöségei}

Debrecen jelenleg használatos (igaz, a turisták számára készült) szlogenje alapján „a napba öltözött város”. Ennek kritikai szempontú értékeléséhez Burgess (1982) azon megállapítása szolgál kiindulási alapul, amely szerint a szlogenek olyan tulajdonságokra hívják fel a figyelmet, mint az életminőség, a település által kínált előnyök és üzleti lehetőségek. Ezt figyelembe véve megállapitható, hogy a napfény, a napsütés nem sorolható a település egyedi előnyei közé. Annál is inkább igaz ez, mert a napsütéses órák száma a hasonló szlogent használó Szegeden („A napfény városa”) magasabb. Az alkalmazott szlogen tartalma teljesen általánosnak tekinthetö, amely nem igazán tükrözi a város jellegzetességeit, értékeit - gazdag kulturális életét, hagyományait, iskolavárosi karakterét, a Nagyerdőt vagy akár a turisták, illetve a befektetők számára kínált lehetőségeket, nem hirdeti annak egyediségét. Holcomb (1994) szavaival élve így a város „alulreklámozottnak” („,undermarketed”) minősíthet”, azaz nem közvetíti a hely termékeit és szolgáltatásait a fogyasztók felé (Kotler et al. 1993).

Felmerülhet a kérdés, hogy egy megfelelőbb, a város lakosságának (is) szóló szlogen esetleges alkalmazásánál felhasználhatók-e az akusztikai környezet előnyei, a települési környezet egyes elemei, például a csendesség vagy az otthonosság, élhetőség.

Első megközelítésben induljunk ki abból a hagyományosnak tekinthető felfogásból, amely szerint a nagyvárost intenzív, lüktető életvitel (nagy forgalom, események, rendezvények, dinamikus gazdasági élet) jellemzi, és nem elsősorban a csendes környezet iránti igény jelenti az önkormányzat számára a település eladhatóságának egyik formáját. A fenntartható várost azonban a szakirodalom kompakt városként vagy kompakt városrészek összességeként írja le, amelyben egyfelől a szigetszerüen, koncentráltan jelentkező környezeti hatások könnyebben kompenzálhatók, semlegesíthetők (fenntarthato.hu 2010), másfelől pedig kis távolságon belül jól megférnek egymás mellett a legkülönbözőbb városi tevékenységek. Butters (2004) ezt a változatosságot, sokszínűséget a fenntartható városfejlesztés társadalmi dimenziójának egyik fó elemeként tünteti fel. (Hazai példa a térbeli kettősség ilyen megjelenésére a vizsgált szlogenek között nem található.) Fentiek értelmében egyegy zajos, forgalommal és rendezvényekkel terhelt belvárosból rövid időn belül elérhető a pihenést maradéktalanul lehetővé tevő, zajmentes lakókörnyezet.

A város lakossága körében elvégzett kérdőives felmérés eredményei azt mutatják, hogy a keleti vagy déli kertvárosokban élók alapvetően (a nagyobb forgalmú utcák kivételével) kedvezően ítélik meg lakóhelyük zajviszonyait, így annak termékként vagy termékelemként történő felhasználása a lakosság mint célcsoport esetében megalapozott. Tekintettel a Debrecen és Nyíregyháza közötti több évtizedes rivalizálásra, valamint arra a tényre, hogy utóbbi város jelmondatában az élhetőségét hirdeti, ennek elmaradása Debrecen esetében versenyhátrányként értelmezhető.

Összességében azt mondhatjuk, hogy a város által jelenleg használt szlogen a Gold és Ward (1994) által leírt, korábban ismertetett 4 elvárás közül lényegében csak a pozitív érzés kialakításának tesz eleget. Az attraktív imázs meglétéhez va- 
ló hozzájárulás megítélése szubjektív, míg a másik két tényezőnek való megfelelés teljes mértékben hiányzik.

\section{A zaj mint környezeti konfliktus kezelésének lehetséges szerepvállalói, a települési önkormányzatok}

Debrecenben, a megkérdezettek lakóhelyén tapasztalható zajterhelés legfontosabb forrásának a közúti közlekedés tekinthető, amelynek zavaró hatása valamelyest erőteljesebben jelentkezik az északi-központi városrészben, gyengébb a déliben, és átlagosnak tekinthető a keleti és nyugati körzetben (2. ábra). Jóval kisebb mértékben érvényesül a vasúti és a légi közlekedés hatása, még a repülőtérnek otthont adó déli városrészben is. A sok önkormányzatnak gondot okozó „diszkókérdés” - a szórakozóhelyek saját hangja és a környezetükben megjelenő éjszakai gépjárműzaj, lármázás - (Dávid 2003) alig tükröződik a lakossági véleményekben.

A zajterhelés a megkérdezettek mintegy 3/4-énél okoz valamilyen mértékű és rendszerességű zavaró hatást, ezek mintegy ötödénél megfigyelhető a zavaráshoz való hozzáidomulás is. A lakóhelyen legerősebben jelentkező zajterhelés a reggeli (6-10 óra között), valamint a délutáni-kora esti (14-18, valamint 18-22 óra) csúcsforgalomhoz kötheto", az éjszakai zajok a megkérdezetteknek kevesebb mint 20\%-át érintik. A terhelés a lakosság mintegy egyharmadánál napi 1-2 óra, közel ugyanennyiüknél 2-5 óra hosszban tapasztalható. (Ehhez adódik az iskolában/munkahelyen „elviselt” zajmennyiség.); ez a helyzet az összes válaszadó mintegy 70\%-ánál legalább 5 éve áll fenn.

Az elvégzett számítások eredményei alapján a zajpanaszindex $\left(\mathrm{z}_{\mathrm{p}}\right)$ értéke 0,08 és 3,91 között alakul a városban. A kapott indexértékek alapján a kérdőívezésbe bevont utcák az alábbiak szerint kategorizálhatók:

- 0-1,00: gyengén zajos utcák,

- 1,01-2,00: közepesen zajos utcák,

- 2,01 fölött: erősen zajos utcák.

A vizsgálatban szereplő utcák közül 83 (61,9\%) gyengén zajos, 34 (25,4\%) közepesen zajos, $17(10,4 \%)$ pedig erősen zajos. A zajpanaszindex átlaga az összes utca vonatkozásában 1,02, míg a legzajosabb 20 utcára számítva 2,55. Az egyes kategóriákon belül, a 4. ábrának megfelelően további alkategóriák különíthetők el, érzékeltetve az egyes csoportokon belüli különbségeket.

A legmagasabb mutatóval a keleti városrész, a kertvárosias beépítéssel jellemezhető Csapókert két utcája, a Budai Nagy Antal és a Veres Péter utca rendelkezik; ezek mellett még kettő (köztük a Piac utca) indexe 3,00 fölötti, a kérdőíves felmérésben szereplő válaszok alapján tehát a zaj okozta zavaró hatások itt jelentkeznek leginkább, így ezen utcák mint lakóhelyek megitélése a legkedvezőtlenebb. Ezeken túlmenően a belvárosban és környezetében található fontosabb közlekedési útvonalak, valamint néhány, a városból kivezető út szerepel a 20 legrosszabb mutatóval rendelkező utca között. 
4. ábra: A város zajpanasztérképe

The town's noise complaint map

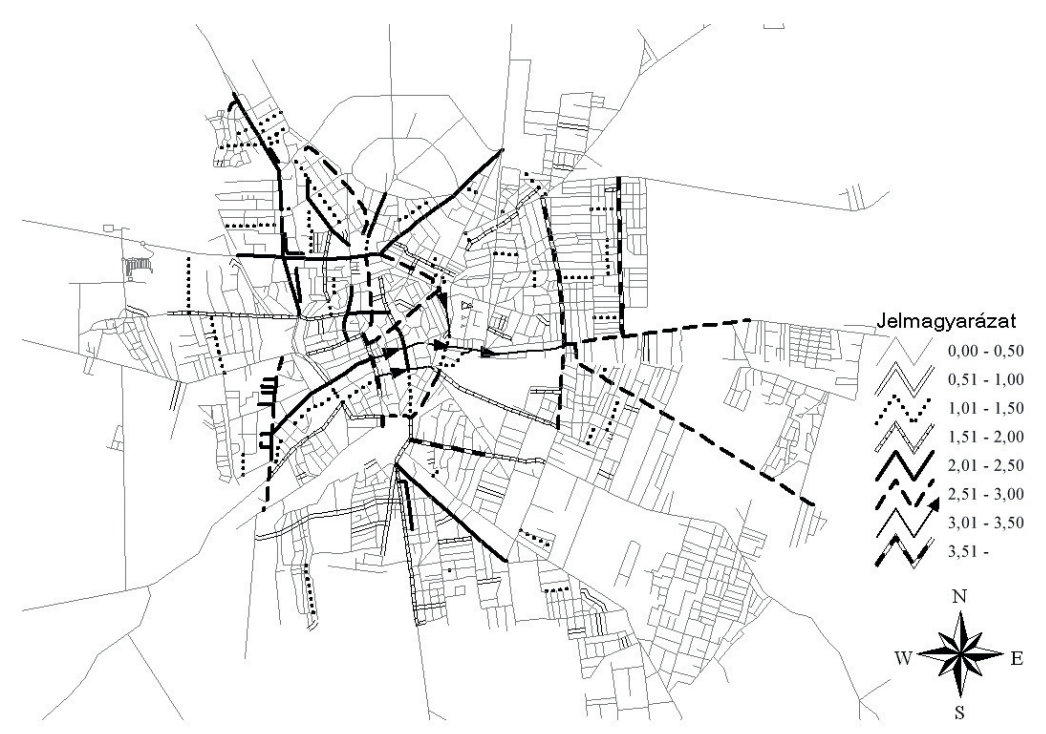

Forrás: saját szerkesztés.

A 20 legzajosabbnak tartott utca területi eloszlásáról elmondható, hogy a déli és nyugati városrészt 3-3 utca képviseli, így ezekről általánosságban pozitív kép rajzolódik ki. Ugyanakkor 7-7 a központi-északi (ebből öt a belvárosban) és a keleti városrészben helyezkedik el - ez utóbbi megítélése, jellemzően kertvárosias beépítése (melytől sokak csendesebb lakókörnyezetet remélnek) miatt tűnik kedvezőtlennek. A központi és a keleti városrészekről alkotott lakossági képet jól tükrözik a 1. táblázat eredményei: mind az adott városrész 3 legmagasabb indexértéket mutató utcájának átlagát $\left(z_{\text {pmзmax }}\right)$, mind pedig ennek és a városrész összes utcájára számított átlagnak a $\left(z_{p m}^{p m 3}\right)$ különbségét $\left(\Delta z_{p m}=z_{p m 3 m a x}-z_{p m}\right)$ tekintve ez a két városrész mutatja a legmagasabb értékeket. A különbség a keleti városrészben a kis forgalmú, gyengén zajosnak minősített utcák nagy számával, valamint az erősen zajosnak tartott utcák magas indexértékeivel magyarázható. A központi városrészben a kiegyenlítettebb $\Delta \mathrm{z}_{\mathrm{pm}}$ érték annak köszönhető, hogy a vizsgált 17 utca közül 13 közepesen vagy erősen zajos minősítést kapott, azaz indexe 1,00 fölötti.

A város legmagasabb indexértékeket mutató utcáinak esetében a zavaró hatások szinte minden esetben (a Piac utca kivételével, ahol részben az ott tartott rendezvényekből, részben pedig) a közúti közlekedésből származnak. Az olyan, közismerten forgalmas utcák, mint például a Wesselényi és a Kossuth u., a Böszörményi és a Füredi út mutatói ettől kisebb-nagyobb mértékben elma- 
1. táblázat: Az egyes városrészekre számított főbb zajpanaszindex-értékek Relevant noise complaint index values as calculated for the designated districts

\begin{tabular}{lccc}
\hline \multicolumn{1}{c}{ Városrész } & $z_{p m}$ & $z_{p m 3 m a x}$ & $\Delta z_{p m}\left(z_{p m 3 m a x}-Z_{p m}\right)$ \\
\hline Keleti & 1,13 & 3,31 & 2,18 \\
Központi-északi & 1,29 & 2,96 & 1,67 \\
Ebböl központi & 1,64 & 2,96 & 1,32 \\
Nyugati & 0,83 & 2,10 & 0,83 \\
Déli & 0,75 & 2,42 & 1,67 \\
\hline
\end{tabular}

Forrás: saját szerkesztés.

radnak. Ez egyfelől azzal magyarázható, hogy a nagyobb közúti forgalomból eredő nagyobb zajterheléshez az érintett utcák lakói valamilyen mértékben hozzászoktak, így sok esetben nem ismerik fel annak egészségre gyakorolt hatásait. Másfelől, a zajpanaszindex értékei azon utcákban a legmagasabbak, ahol a közepes vagy magas forgalomhoz sürü beépítés társul, illetve az úttesthez mérten a védendő homlokzatok kis távolságra helyezkednek el. Ezt támasztja alá az is, hogy sok esetben a sűrü beépítésü, közepes közúti forgalommal terhelt utcákban (pl. Szabó Kálmán utca, Létai út, Nyíl utca) a zajterhelés megítélése lényegesen rosszabb, mint egyes nagyobb forgalmú utcákban (pl. Erzsébet utca, Mikepércsi út).

A felmérésben részt vevők döntő többsége felismerte a zaj valamilyen jellegü és mértékü egészségkárosító hatását. Közel kétharmaduk családjánál semmilyen, az elviselt zajnak tulajdonított tünet nem figyelhető meg, és a zajterhelés életvitelre gyakorolt hatásai állandó jelleggel az érintettek otthonainak is csak igen csekély hányadában jelentkeznek. A valamilyen rendszerességü hanghatások a válaszadók több mint 30\%-át zavarják az éjszakai alvásban, a kikapcsolódásban, a koncentrálóképesség csökkenésében.

Ez a nem túl kedvező helyzet a megkérdezettek mintegy kétharmada szerint javítható, és további tizede szerint szüntethető meg teljesen. A kérdőíves felmérés eredményeiből kitűnik, hogy a Debrecenben jelentkező zajprobléma megoldásában a válaszadók több mint 70\%-a az önkormányzattól vár segítséget (5. ábra), azaz a lakosság a probléma megoldását egyértelmüen az önkormányzat feladatának tekinti. A megkérdezettek közel kétharmada szerint ugyanakkor jelenleg a településen nem fektetnek elég hangsúlyt a zajjal kapcsolatos problémák kezelésére. A hatékonyabb megoldás érdekében felmerül a város- és környezetvédő civil mozgalmakkal történő együttműködés szükségszerüsége melyek, többek között, közvetítő eszközként fontos szerepet játszhatnak a város-termék előnyös tulajdonságainak terjesztésében (Probáld 1995) -, ugyanakkor a vizsgálat szerint a civil szervezeteket alig tekintik lehetséges szereplőnek.

A felmérésben részt vevők a Debrecenben jelentkező zajterhelés csökkentése érdekében az alábbi intézkedéseket tartják fontosnak: a várost elkerülő út megépítése, a már meglévő belvárosi sétálóövezet bővítése, zöldövezetek kialakítása és a teherforgalom időbeli korlátozása. A szigorúbb törvényi szabályozás, az aktív zajvédelem klasszikus módszereinek alkalmazása, illetve a csendes 
5. ábra: A kezdeményező szerepének megítélése a települési zajterhelés mint probléma megoldásában Debrecenben

Public opinions on the role of initiators in solving noise nuisance related problems in Debrecen

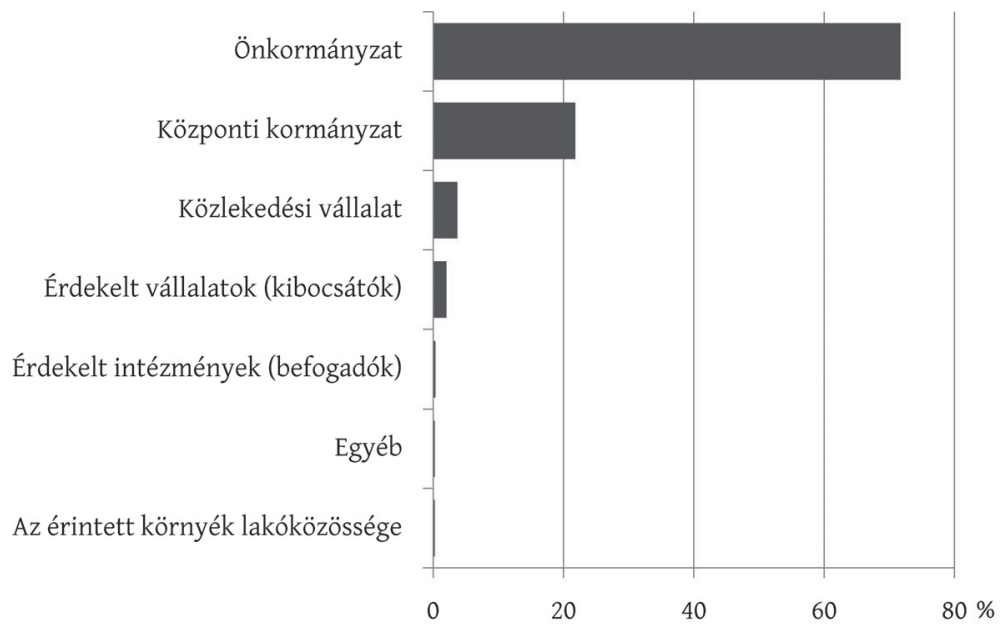

Forrás: Baros 2009.

övezetek kialakítása irányában mutatkozó igény a válaszok kisebb arányában jelenik meg.

Ezek egy része olyan forrásigényes beruházást jelent, amelynek megvalósítása csak több lépcsőben, lassan történhet meg, azaz valós eredményt csak közép- vagy hosszú távon hozhat. Azonban az adminisztratív eszközök alkalmazása sem lehet mindig zökkenőmentes. Az önkormányzatok ugyanis nem alkothatnak a központi jogszabályoknál enyhébb jogi rendelkezéseket, nem puhíthatják fel a központi előírásokat. Másrészt az önkormányzatok a központi jogszabályokhoz képest szigorúbb zajvédelmi szabályokat csak akkor vezethetnek be, ha törvény vagy kormányrendelet már előzetesen meghatározta a helyi önkormányzati jogalkotás módját és mértékét, tehát a tényleges kereteket (Vizeli 2006). Ilyen rendeletalkotási keretet adó szabályozás pedig jelenleg nincs hatályban. Helyi rendeletekkel (pl. üzletek éjszakai nyitvatartási idejének korlátozásával) ugyanakkor indirekt módon bizonyos zajforrások mérsékelhetők vagy megszüntethetők, így a zajhelyzet javítható.

\section{Következtetések}

A környezeti minőség, a jobb akusztikai környezet elérése és reklámozása tekintetében az önkormányzatok feladatainak az alábbiak tekinthetők: 
- a probléma felszámolása,

- a fenti szempontok beépítése marketingtevékenységükbe,

- tudatformálás a lakosság és más érdekeltek körében.

Az elvégzett vizsgálatok eredményéből megállapítható, hogy a lakosság a városi zajterhelés csökkentésében elsődleges szerepet tulajdonít az önkormányzatnak, amely forráshiánya, illetve adminisztratív korlátai miatt ennek az elvárásnak nem minden esetben tud megfelelni. Arra is fel kell ugyanakkor hívni a figyelmet, hogy a zajprobléma többféle intézkedés együttes alkalmazásával, valamint több érintett szereplő (lakosság, civil szervezetek) bevonásával javítható hatékonyan.

A hazai települések marketingtevékenységének a szlogeneket érintő szegmensében a települési környezet minősége háttérbe szorul. Ebből következően az ilyen típusú előnyökben rejlő lehetőségeket alig használják ki, az alkalmazott szlogenek az esetek többségében nem járulnak hozzá a település adottságainak, értékeinek reklámozásához. Ehelyett saját központi helyzetüket, az ebből következő vélt vagy valós versenyelőnyüket hangsúlyozzák. Olyan biztonsági megoldást alkalmaznak ezzel, amellyel - az innovatív megoldások mellőzésével - egyúttal konzerválják a nyugat-európai önkormányzatokkal szembeni lemaradásukat.

A lemaradás csökkentésére, a felzárkózásra a hazai és nemzetközi partnerségek kialakítása, illetve az azokhoz történő csatlakozás kínál jó lehetőséget. Ez nemcsak hírnevet hozhat a településnek, hanem a tényleges fejlesztések megvalósítását is elősegítheti. Nemzetközi szinten ilyen lehet, többek között, az URBACT programhoz vagy a Slow City elnevezésủ mozgalomhoz való csatlakozás; hazai viszonylatban pedig az Egészséges Városok Szövetsége vagy a Klímabarát Települések Szövetsége érdemel említést.

A lakosság zajterheléssel kapcsolatos ismereteiben, környezeti tudatosságában jelentkező hiányosságok felszámolásában az önkormányzat szerepének egyik megnyilvánulási formája lehet egy a környezeti értékek felhasználását és fejlesztését célzó koncepció vagy program kidolgozása és végrehajtása. Ennek fókuszában, az elvégzett felmérés eredményeit figyelembe véve, a zajártalommal és egészségi hatásaival, a stratégiai zajtérképekkel, valamint a zajvédelemmel (épületek zajszigetelése, zajcímkézés, az egyén közlekedési, termékvásárlási és viselkedési szokásainak befolyásolása-megváltoztatása, a mindezekből következő előnyök bemutatása) kapcsolatos ismeretek átadásának kell állnia. Szerencsés esetben az önkormányzat által alkalmazott szlogen ennek elemét képezi, illetve részben vagy teljes egészében utal erre.

\section{Irodalom}

Axelsson, A. (1996): Recreational exposure to noise and its effects. Noise Control, Eng J., 44., 127-134. Ashworth, G. J., Voogd, H. (1994): Marketing and Place Promotion. In: Gold, J. R., Ward, S. V. (eds.): Place Promotion - The Use of Publicity and Marketing to Sell Towns and Regions. John Wiley \& Sons Ltd., Chichester, 39-52. 
Ashworth, G. J., Voogd, H. (1997): A város értékesitése. Közgazdasági és Jogi Könyvkiadó, Budapest

Barke, M., Harrop, K. (1994): Selling the Industrial Town: Identity, Image and Illusion. In: Gold, J. R., Ward, S. V. (eds.): Place Promotion - The Use of Publicity and Marketing to Sell Towns and Regions. John Wiley \& Sons Ltd., Chichester, 93-114.

Baros Z. (2009): Lakossági részvétel a települési zajvédelemben. A II. Települési konferencia (Debrecen, 2009. november 27-28.) előadáskötete, Debreceni Egyetem Tájvédelmi és Környezetföldrajzi Tanszék, Debrecen, 94-99.

Baros Z., Gajdátsy P. (2008): A közúti közlekedésból eredő zajterheléshez kapcsolódó lakossági vélemények Debrecen városában. A Települési Környezet Konferencia (Debrecen, 2007. november 8-10.) elöadáskötete, Kossuth Egyetemi Kiadó, Debreceni Egyetem, Debrecen, 134-139.

Berki M., Csapó J. (2006): Comparative Analysis of Competitiveness in the Major Cultural Cities of Hungary. In: Aubert A., Tóth J. (Hrsg): Stadt und Region. Pécs, Beiträge zur angewandten Stadt- und Wirtschaftgeographie. Universität Bayreuth, Bayreuth, 49-65.

Bite P-né, Póta Gy-né (2001): EU-irányelvek és azok érvényesítése a hazai közlekedési zajvédelemben. Közlekedéstudományi Szemle, 7., 241-256.

Bogunovich, D. (2009): From Planning Sustainable Cities to Designing Resilient Urban Regions. In: Tiezzi, E., Marques, J. C., Brebbia, C. A., Jørgensen, S. E. (eds.): Sustainable Development and Planning IV. WIT Transactions on Ecology and the Environment, Wessex Institute of Technology, WIT Press, UK., 87-96.

Burgess, J. A. (1982): Selling Places: Environmental Images for the Executive. Regional Studies, 16., $1-17$.

Bujdosó Z. (1999): Városmarketing és területfejlesztés kapcsolata egy kisváros példáján. Kézirat, Debreceni Egyetem, Debrecen

Butters, C. (2004): A Holistic Method of Evaluating Sustainability - http://www.gaiaoslo.no/artikler.html Letöltés: 2007. márc. 5.

Cadbury, G. Jnr. (1915): Town Planning with Special Reference to the Birmingham Schemes. Longmans Green, London

Csete M. (2007): Klímaváltozás és a települések fenntarthatósága. „Klíma 21” füzetek: Klímaváltozás Hatások - Válaszok, 51., 71-88.

Dávid L. (szerk.) (2003): Az Észak-alföldi Régió Környezetvédelmi Programja. Észak-alföldi Regionális Fejlesztési Ügynökség, Debrecen

Díaz, C., Pedrero, A. (2006): Sound exposure during daily activities. Applied Acoustics, 67., 271-283.

Drakakis-Smith, D. (1980): Urbanisation, Housing and the Development Process. St. Martin's Press, New York

Dövényi Z., Kovács Z. (2006): Urban Development in Hungary after 1990. In: Altrock, U., Güntner, S., Huning, S., Peters, D. (eds.): Spatial Planning and Urban Development in the New EU Member States. Aldershot, Ashgate, 163-179.

Elekes T. (2008): A földrajzi tényezök szerepe a településfejlődésben. Dialóg Campus Kiadó, Budapest-Pécs

Fojtik J. (1999): Városmarketing az interneten - lehetőségek és eredmények. Tér és Társadalom, 1-2., 75-88.

Garamhegyi Á. (2000): Településmarketing mint a településfejlesztés eszköze. PhD-dolgozat, Szeged

Gardiner B., Martin R., Tyler P. (2004): Competitiveness, Productivity and Economic Growth across the European Regions. Regional Studies, 9., 1045-1067.

Gold, J. R., Ward, S. V. (eds.) (1994): Place Promotion - The Use of Publicity and Marketing to Sell Towns and Regions. John Wiley \& Sons Ltd., Chichester

Gyenizse P. (2009): Hogyan értékelik a települési környezetük térbeli elemeit néhány magyarországi nagyváros lakói? A II. Települési Környezet Konferencia (Debrecen, 2009. november 27-28.) előadáskötete, Kossuth Egyetemi Kiadó, Debreceni Egyetem, Debrecen, 272-277.

Herendy Cs., Murányi P. (2009): „Ráncfelvarrás” online - innovatív platformok a településmarketingben. A II. Települési Környezet Konferencia (Debrecen, 2009. november 27-28.) elöadáskötete, Kossuth Egyetemi Kiadó, Debreceni Egyetem, Debrecen, 247.

Herzog, T. R. (1989): A Cognitive Analysis of Preference for Urban Nature. Journal of Environmental Psychology, 9., 27-43. 
Holcomb, B. (1994): City Make-overs: Marketing the Post-industrial City. In: Gold, J. R., Ward, S. V. (eds.): Place Promotion - The Use of Publicity and Marketing to Sell Towns and Regions. John Wiley \& Sons Ltd., Chichester, 115-132.

Izsák É., Probáld F. (2008): Klimatikus környezet és városfejlesztés Budapesten. A Települési Környezet Konferencia (Debrecen, 2007. november 8-10.) előadáskötete, Kossuth Egyetemi Kiadó, Debreceni Egyetem, Debrecen, 116-121.

Izsák É., Probáld F., Uzzoli A. (2008): Természeti adottságok és életminőség Budapesten. A IV. Magyar Földrajzi Konferencia (Debrecen, 2008. november 14-15.) előadáskötete, CD-kiadvány

Kang, J. (2005): Urban Acoustics. Applied Acoustics, 66., 121-122.

Kiss A. (2006): A tudatos városfejlesztés. Táj, környezet és társadalom - Ünnepi tanulmányok Keveiné Bárány Ilona professzor asszony tiszteletére, Szeged, 363-372.

Koncz G. (2008): Településállomány, településhálózat, térszerkezeti sajátosságok. In: Baranyi B. (szerk.), Horváth Gy. (sorozatszerk.): Észak-Alföld. A Kárpát-medence régiói 8. MTA Regionális Kutatások Központja és Dialóg Campus Kiadó, Pécs-Budapest, 390-425.

Kotler, P., Haider, D. H., Rein, I. (1993): Marketing Places: Attracting Investment, Industry and Tourism to Cities, States an Nations. Macmillan, New York

Kovács A. D. (2006): A környezeti tudatosság területfejlesztésben betöltött szerepe alföldi példákon keresztül. III. Magyar Földrajzi Konferencia, 2006. szeptember 6-7. Budapest (Kertész Á., Dövényi Z., Kocsis K. szerk.). MTA FKI, Budapest, CD-ROM

Kozma G. (2002): Terület-és településmarketing. Kossuth Egyetemi Kiadó, Debrecen

Kozma G. (2005): Szlogenek és jelképek a hazai idegenforgalmi marketingben. Comitatus - Önkormányzati Szemle, 11-12., 147-154.

Kwan, M-P. (2004): Beyond difference: from canonical geography to hybrid geographies. Annals of the Association of American Geographers, 94., 756-763.

Lichtenberger, E. (1993): Stadtökologie und Socialgeographie. In: Sukopp, H., Wittig, R. (eds.): Stadtökologie. Gustav Fischer Verlag, Stuttgart, 10-45.

Lengyel I. (2000): A regionális versenyképességről. Közgazdasági Szemle, 47., 962-987.

Maderthaner, R. (1995): Soziale Faktoren urbaner Lebensqualität. In: Keu, A. G. (ed.): Wohlbefinden in der Stadt, Umwelt- und gesundheitspsychologische Perspektiven. Weinheim: Beltz, PVU.

Magyar Tudományos Akadémia Műszaki Tudományok Osztálya Akusztikai Komplex Bizottság (2003): A környezeti zaj elleni védelem magyarországi helyzete és a fejlesztés stratégiája, különös tekintettel az EU-követelményekre. Budapest

Málovics Gy., Ván H. (2008): Az ökológiai fenntarthatóság és a regionális versenyképesség összefüggései. Tér és Társadalom, 2., 21-40.

Meier, R. L. (2003): Ecological Planning, Management, and Design. Online kézirat: http://www.ced.berkeley.edu/pubs/faculty/meier_richard/ecoplanmgmtdes/(Letöltés: 2006.11.01.)

Nagy B. (2005): A település, az épitett világ. GEO-Könyvek, B+V (medical\&technical) Lap- és Könyvkiadó $\mathrm{Kft}$.

Nardo, M. (2004): Noise Pollution: An Overview of Management Strategies. International Journal of Environmental Technology and Management, 4., 300-322.

Penn-Bressel, G. (1988): Verkehrslärm und Wohnstandortverhalten. Informationsdienst un Mitteilungsblatt des deutschen Volksheimstättenwerks, 41., 145-148.

Piskóti L., Dankó L., Schupler, H. (2002): Régió- és településmarketing. KJKKERSZÖV, Budapest

Popp, C. (2004): Sound City - The EU environmental noise directive. Challenges and potential solutions at local level. Zajvédelmi szeminárium, Környezetvédelmi és Vízügyi Minisztérium és az European Academy of the Urban Environment, Berlin (Budapest, 2004. június 10.)

Próbáld K. (1995): Városmarketing I-II. Comitatus 1995. december - 1996. január

Rechnitzer J. (szerk.) (2007): Település és fejlesztés: A közszolgáltatások hatékonyságának növelése a településfejlesztésben. KSZK ROP, Budapest

Skinner, C. J., Grimwood, C. J. (2005): The UK noise climate 1990-2001: population exposure and attitudes to environmental noise. Applied Acoustics 66., 231-243.

Vizeli S. (2006): A települési önkormányzatok feladatai a zaj elleni védelem területén. A zajvédelem aktuális kérdései (Zajvédelmi szeminárium: Debrecen, 2006. november 8-10.), OPAKFI, CD-kiadvány

Ward, S. V. (1998): The Marketing and Promotion of Towns and Cities 1850-2000. E \& FN Spon, London 


\section{Baros Zoltán}

World Bank (2000): Cities in Transition. World Bank Urban and Local Governments Strategy. World Bank, Washington

Yilmaz, H., Özer, S. (2005): Evaluation and analysis of environmental noise pollution in the city of Erzurum, Turkey. International Journal of Environment and Pollution, 4., 438-448.

http://fenntarthato.hu/epites/leirasok/telepules/telepules-terulethasznalat/

index_html\#---a-fenntarthat-s-g-m-rhet-s-ge Letöltés: 2010. febr. 24.

http://members.upclive.hu/d.molnar1/mozgalom/cserehat_ajanl.htm Letöltés: 2010. aug. 12. 